\title{
豚の下痢症に対するサルファジメトキシンの応用
}

本好茂一* 加納康彦*三浦高義*

（昭和 37 年 6 月 9 日受付）

サルファ剤は化学療法剤として家畜の内科的および外 科的疾患に対して広く応用されている。 また近年は家畜 や家禽の多頭羽飼育の発達に伴ない, 疾病予防の面に拈 いても沉用されている。

一方サルファ剂自体には新らしい誘導体が次々に合成 され，サルファ剤の大きい欠点とされていた有効血中濃 度の持続時間の短少, 内服による胃腸障害, 腎障害, 尿 路結石の形成, その他嘔吐, 頭痛, めまい, 顆粒白血球の 減少なぞの点が著るしく改良されてきた，その新らしい 誘導体の 1 つとしてサルファジメトキシンがある。本剤 は 4-p-Aminobenzene Sulfanylamino-2・6-dimethoxy Pyrimidine の構造をもち, 従来のサルファ剤の適応と されていた各種感染症に有効であるばかりでなく，比較 的少量の投与で血中有効濃度の持続時間が長く, 組織へ の滲透力が強く、アセチール化は汪とんど行なわれず, グルクロナイドとして排泄されるための尿路結石形成や 血尿乞の他の副作用が少ないなどの特徴を有している. 本剤は無味無臭で白色の結晶性粉末であるが，ここで使 用したものは $\mathrm{Na}$-塩の $10 \%$ 溶液である。<smiles>COc1cc(NS(=O)(=O)c2ccc(N)cc2)nc(OC)n1</smiles>

われわれは豚において実験的に血中濃度の測定を行な い，かつ多数の子庰の下痢症に対して応用し治療効果の 高いことを認めたので報告する．

\section{I 血中濃度測定成績}

Bratton-Marshall の比色法に従って血中濃度を定量 した.

\section{1）体重 $1 \mathrm{~kg}$ 当り $20 \mathrm{mg}$ 筋注群}

使用した豚は健康と思われる体重 $60 \mathrm{~kg}, 60.8 \mathrm{~kg}$ および $55.8 \mathrm{~kg}$ の 3 頭を用いて, 総量掞よび遊離型值 ( 1 頭 No. 2 号豚のみ）を測定した。測定は投与後 $1,2,4,6$, 8,16 および24の各時間の 7 回行なった。第 1 表および 第 1 戝にその成績を示した。

2) 体重 $1 \mathrm{~kg}$ 当り $20 \mathrm{mg}$ 筋注後 8 時間目にさらに $10 \mathrm{mg} / \mathrm{kg}$ を追加した群

\section{* 東京大学農学部附属牧場}

日獣会誌 16 (1963)
第 1 表 $20 \mathrm{mg} / \mathrm{kg}$ 血中濃度

\begin{tabular}{|c|c|c|c|c|c|c|c|c|}
\hline 番号 & 時 間 & $1^{\circ}$ & $2^{\circ}$ & $4^{\circ}$ & $6^{\circ}$ & $8^{\circ}$ & $16^{\circ}$ & $24^{\circ}$ \\
\hline No. 1 & Total & 7.0 & 6.5 & 5.75 & 4. 6 & 4.2 & 2.3 & 1.8 \\
\hline No. 2 & $\left\{\begin{array}{l}\text { Free } \\
\text { Total }\end{array}\right.$ & $\begin{array}{l}6.2 \\
6.2\end{array}$ & $\begin{array}{l}5.7 \\
5.7\end{array}$ & $\begin{array}{l}6.5 \\
4.3\end{array}$ & $\begin{array}{l}3.7 \\
4.0\end{array}$ & $\begin{array}{l}3.7 \\
2.3\end{array}$ & - & $\begin{array}{l}1.6 \\
1.6\end{array}$ \\
\hline No. 3 & Total & 6.4 & 6.4 & 4.5 & 3.5 & 3.0 & 2.8 & 1.8 \\
\hline
\end{tabular}

第 1 図 $20 \mathrm{mg} / \mathrm{kg}$ 投与の血中濃度

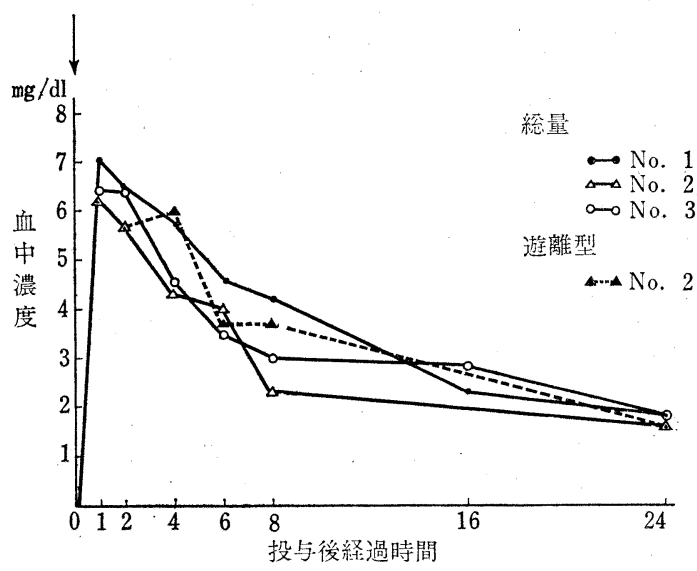

最初に $20 \mathrm{mg} / \mathrm{kg}$ を投与し 8 時間の後に $10 \mathrm{mg} / \mathrm{kg}$ を追加 注入すると，かなり持続時間の延長が可能であろらとの 想定から， 2 頭の豚を用いて測定した. その結果は第 2 表および第 2 図に示す通りである. 供試豚の体重はいず れも $50.3 \mathrm{~kg}$ であった。

\section{3）体重 $1 \mathrm{~kg}$ 当り $40 \mathrm{mg}$ 筋注群}

$40 \mathrm{mg} / \mathrm{kg}$ を筋注しその血中濃度を同様の方法で測定し た. 使用した 2 頭の豚の体重はそれぞれ $49.5 \mathrm{~kg}$ と 57.5 $\mathrm{kg}$ であった．結果は第 3 表抢よび第 3 図の通りである.

以上の成績を総括すると次の通りである．体重50 60 $\mathrm{kg}$ のヨークシャー種豚にサルファジメトキシン $\mathrm{Na}$-塩の

第 2 表 $20 \mathrm{mg} / \mathrm{kg}+10 \mathrm{mg} / \mathrm{kg}$ 血中濃度 豚番号 $1^{\circ} 2^{\circ} 4^{\circ} 6^{\circ} 8^{\circ} 9^{\circ} 10^{\circ} 12^{\circ} 14^{\circ} 16^{\circ} 24^{\circ} 32^{\circ}$

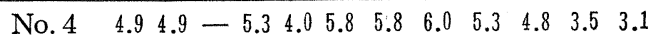

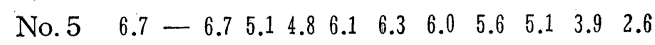
単位 $\mathrm{mg} / \mathrm{dl}$ 
第 2 図 $20 \mathrm{mg} / \mathrm{kg}+10 \mathrm{mg}$ 血中濃度

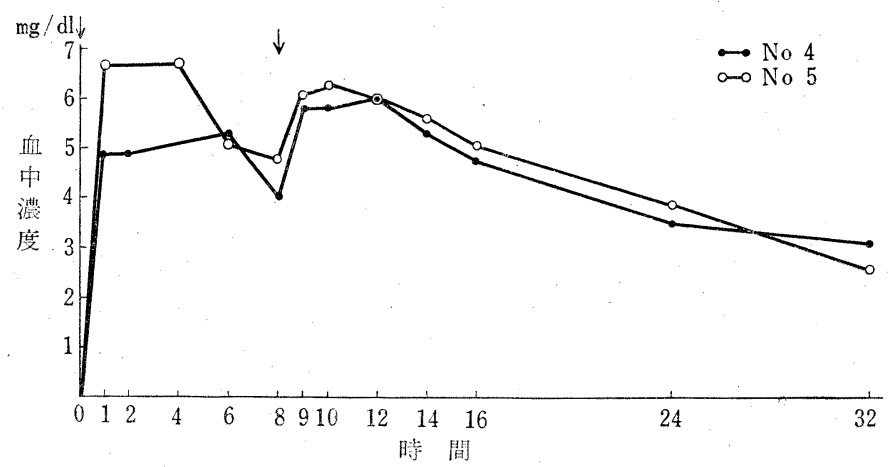

第 3 表 $40 \mathrm{mg} / \mathrm{kg}$ 血中濃度

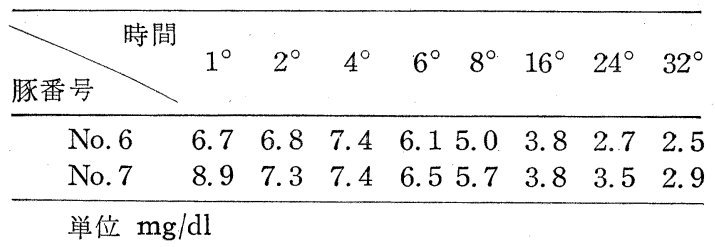

第 3 図 $40 \mathrm{mg} / \mathrm{kg}$ 血中濃度

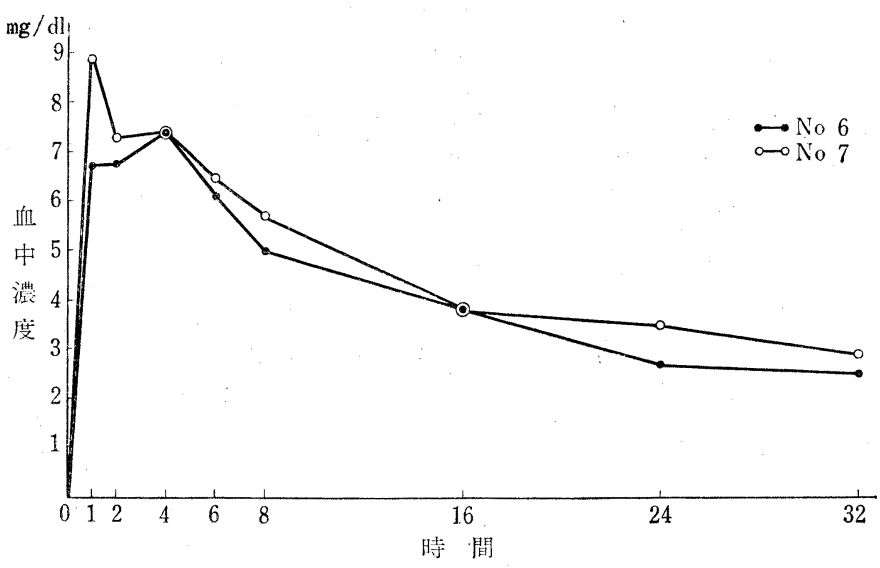

する最低濃度を抜き書きして見ると次の通 りである. (単位は $\mathrm{mg} / 100 \mathrm{cc}$ )

Aerobacter aerogenes $\quad 0.16$

Brucella bronchiseptica $\quad 0.31$

Corynebacterium pyogenes $>80.0$

Escherichia coli $\quad 0.04$

Pasturella suiseptica $\quad 2.5$

Salmonella cholerasuis $\quad 0.63$

Staphylococcus aureus $\quad 0.63$

Streptococcus agalactiae. $\quad 5.0$

Streptococcus pyogenes $\quad 10.0$

一方サルファジメトキシンの諸種病原菌 に対する試験管内発育阻止濃度を換算し表 示すると6) $(\mathrm{mg} / \mathrm{dl})$.

$\begin{array}{ll}\text { Sta. aureus, } 209 P & 0.31 \\ \text { Sta. aureus, } 188 & 0.63 \\ \text { Str. hemolyticus } & 2.5 \\ \text { D. pneumoniae I } & 5.0 \\ \text { N. gonorrhoae } & 1.25 \\ \text { Sh. dysenteriae I } & 0.31 \\ \text { S. typhi A } & 2.5 \\ \text { E. coli, B-19 } & 5.0 \\ \text { C. diphtheriae } & 1.25 \\ \text { Prot. vulgaris } O X-19 & 0.31\end{array}$

であり, 黄色ブドウ球菌, 赤痢菌および変 形菌に対してとくに顕著な発育阻止を示 于.

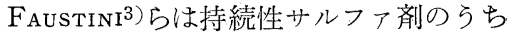
サルファメトキシピリダジンおよびサルフ アピラジンメトキシンを豚に対して100mg $\sim 200 \mathrm{mg} / \mathrm{kg}$ (経口) または $150 \mathrm{mg} / \mathrm{kg}$ (腹腔 内注射) を投与した結果，24時間後の血中 濃度は前者について $100 \mathrm{mg}$ (経口)群では $5.9 \sim 8.7 \mathrm{mg} / \mathrm{dl} ， 150 \mathrm{mg}$ (腹腔内注射) 群 $10 \%$ 液を筋肉内に注射しその血中濃度の推移を測定し た. WeLSH8)らが既に報告しているよらに，大抵の家畜 ではサルファ剤のア七チール化は非常に軽度である。こ のことはわれわれの測定成績（豚 No.2）に沶いても認 められた。

従来サルファ剤による治療では 1 回に 1 grain/lb ( $143 \mathrm{mg} / \mathrm{kg}$ ) 1/2 grain/lb のような大量の投与が行なわ れている．もちろん病性により高い血中濃度の持続を要 求される場合もあるが，一般にはそれほど高い血中濃度 の必要もないわけである。 DETWEILER ${ }^{1)}$ らは in vitro に扮けるいろいるなサルファ剤の各種細菌に対する発育 阻止濃度を示している。 また FLORESTANO4) らも 9 種の サルファ剤の各種細菌に対する最低発育阻止濃度を示し ている. 1 例としてここに Sulfathiazol の各種細菌に対
では9.2〜 $19.5 \mathrm{mg} / \mathrm{dl}$ を保ち，後者においては $100 \mathrm{mg}$ (経口) 群では5.0 8.7mg/dl, 150mg（腹腔内注射）群 では6.5〜16.5mg/dl を示すと報告している.

われわれは比較的少量の投与，すなわち初回に $20 \mathrm{mg} /$ $\mathrm{kg}$ を投与し， 8 時間後にその半量 $(10 \mathrm{mg} / \mathrm{kg})$ を追加注 中濃度が維持されること. また $40 \mathrm{mg} / \mathrm{kg} 1$ 日 1 回だけ の注射ではそれよりもわずかに低いが，やはり十分に高 い水準が保たれることを知った.

さらにここでは血中濃度の測定は行なっていないが， 先ず $40 \mathrm{mg} / \mathrm{kg}$ を投与し， 8 時間後に $20 \mathrm{mg} / \mathrm{kg}$ の追加注 射を行なえば一層良好な結果が得られるであろう。前記 の FAUSTINI らの成績からサルファジメトキシンも大量 の投与を行なえば注射回数は一層削減されるものと推察 射すれば，24時間以上にわたって $3 \mathrm{mg} / \mathrm{dl}$ 以上の高い血 
される。

な衫参考までに乳汁中への移行をしらべたところ，20 $\mathrm{mg} / \mathrm{kg}$ 筋注後, 4 時間では $0.32 \mathrm{mg} / \mathrm{dl}, 8$ 時間では 0.3 $\mathrm{mg} / \mathrm{dl}$ を示し, 非常に微量ではあるが乳中に移行するこ とが認められた。

すなわちわれわれは人間に和けると同様ないしはとれ に近い投与法を目標にして，豚にサルファジメトキシン を注射した結果, 従来の家畜の疾病治療の際に投与され ている他のサルファ郕の用量に比較して $2,3,7)$. 相当に少 ない量で，すなわち， $20 \mathrm{mg} / \mathrm{kg} \sim 40 \mathrm{mg} / \mathrm{kg}$ の投与量でも 適正に行なわれるならば，かなり高い血中濃度が持続し て抗菌作用を呈することを知った。

\section{II 臨床応用成績}

第 4 表に示す通りで発症治療順に揭げてある. 哺乳子 豚拉よび同一豚房内に同一条件で飼養されているものは まとめて最低と最高の体重を記しな和下段にAとして
平均体重を併記した。

投与法としてはすべての例において筋肉内に注射を行 なった。用量拉よび用法については大体初回 $20 \mathrm{mg}$ な は $40 \mathrm{mg} / \mathrm{kg}$ を，次回すなわち 8 時間後にその半量 10 $\mathrm{mg}$ なは $20 \mathrm{mg} / \mathrm{kg}$ を投与し, 同様の投与を数日繰り返 えしたものが多い，供用した豚はすべて本牧場に飼養さ れているるのである.

豚下痢症 子豚和よび中豚に打注る下㾥は発症の頻度 が高く，原因は複雑である，元来下痢症の病名も適当で ないかも知れないが，臨床上下痢を主徴とし，寄生虫畉 の検出が認められず, 疫学的に伝染性の病状を示さず, 激烈な胃腸炎を思わせるような粘血便，または赤色血様 便はなく，一般に子豚は死にいたる程症状はひどくない が，発育の阻害が示されるようなものは一応この範团に 考光て治療の対象とした。

DUNNE2)の編著の中にも記載されているColibacillosis に近いものとも考兄られ，また越智の幼獣下痢症のう

第 4 表 サルファジメトキシンの豚の下痢症に対する応用例（治療順）

\begin{tabular}{|c|c|c|c|c|c|c|c|c|c|}
\hline 番号 & 性 & 年令 & 体重(kg) & 因 & 主要 症 状 & 使 用 法 & 日 & 経 & 効果 \\
\hline 1 & $\not ð$ & 4 カ月 & 38.5 & グラム(一)桿菌 & $\begin{array}{l}\text { T39.3 39.1 } \\
\text { 軟泥便灰色 }\end{array}$ & $0 \otimes \theta$ & 3 & 投与翌日下痢軽度 & H \\
\hline 2 & $"$ & $"$ & 37.5 & $"$ & $\begin{array}{l}\text { T } 39.7 \\
\text { 泥状便臭父強乙 }\end{array}$ & $\theta$ & 1 & 翌日軽快 & \# \\
\hline 3 & $" 1$ & $"$ & 30.6 & - & T 39.8 泥状便 & $\bigcirc \Delta \Delta \Delta \Delta$ & 5 & 4 日目で完治 & \# \\
\hline 4 & "I & " & 34.0 & - & T 40.0 泥状便 & $\bigcirc \Delta \Delta \Delta$ & 4 & 3 日目で治ゆ & \# \\
\hline 5 & " & 5 カ月 & 66.5 & グラム (一)桿菌 & T39.6 泥状便 & $O \triangle \triangle$ & 3 & 完治 & H \\
\hline 6 & " & " & 58.0 & - & T39.5 泥 便 & $O \triangle$ & 2 & 軽快 & H \\
\hline 7 & $" 1$ & 7 カ月 & 73.0 & 一 & 重症, 泥水様便 & $(0) \theta$ & 2 & 完治 & $\#$ \\
\hline $8 \sim 18$ & $\begin{array}{l}\hat{0} 6 \\
\$ 55\end{array}$ & 25 日 & $\begin{array}{l}\text { 4. } 0 \sim 7.0, \\
\text { A } 5.9\end{array}$ & グラム(一)桿菌 & 扊白色～黄灰色便 & 00000000 & 8 & 自由放牧で速に治る & \pm \\
\hline $19 \sim 30$ & $\begin{array}{l}\$ 9 \\
\$ 9\end{array}$ & 20日 & $\begin{array}{l}1.5 \sim 3.7 \\
\text { A } 4.6\end{array}$ & グラム(一)桿菌 & 水様白脷, 悪臭放つ & 0000 & 4 & 放牧後治ゆ & + \\
\hline $31 \sim 33$ & $\begin{array}{l}\hat{0} 1 \\
\circ 2\end{array}$ & 57日 & $\begin{array}{l}11 \sim 14.2 \\
\text { A13.1. }\end{array}$ & - & 重度の白痢臭気年 & $\odot$ & 1 & 1 日投与で治ゆ & \# \\
\hline $34 \sim 35$ & $\begin{array}{l}\hat{o} 1 \\
01\end{array}$ & 84日 & $9.6,11.6$ & - & 発育悪く泥状便 & $\odot$ & 1 & 軽快 & H \\
\hline $36 \sim 41$ & 우 6 & 40 日 & $\begin{array}{l}7.6 \sim 10.9 \\
\text { A } 9.6\end{array}$ & - & 灰色の泥状便 & (○○○@( & 6 & 5 日目固形化 & + \\
\hline $42 \sim 52$ & $\begin{array}{l}\hat{1} 1 \\
\text { o } 10\end{array}$ & 20 日 & $\begin{array}{l}2.3 \sim 4.9 \\
\text { A3. } 6\end{array}$ & - & 白色下痢 & $\Omega$ & 1 & & H \\
\hline $53 \sim 54$ & $\begin{array}{l}\hat{0} 1 \\
01 \\
01\end{array}$ & 98日 & $20.0 \sim 28.9$ & - & 水様消化不良便 & 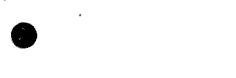 & 1 & 治効著 & H \\
\hline $55 \sim 56$ & $\begin{array}{l}\hat{0} 1 \\
\text { op } 1\end{array}$ & 57日 & $14.6,16.0$ & - & 水射状白痢 & O & 1 & 黒色固形雃となる & H \\
\hline $57 \sim 64$ & $\begin{array}{l}\text { o } 5 \\
\text { o } 3\end{array}$ & 20日 & $\begin{array}{l}1.3 \sim 7.1 \\
\text { A } 5.1\end{array}$ & - & 黄色下痢 & (@)( & 4 & & \# \\
\hline $65 \sim 72$ & $\begin{array}{l}106 \\
\$ 2\end{array}$ & 40日 & $\begin{array}{l}2.8 \sim 9.9 \\
\text { A } 7.7\end{array}$ & - & 軟泥便悪臭なし & ○() & 2 & & \# \\
\hline $73 \sim 83$ & $\begin{array}{l}\hat{o} 7 \\
0+4 \\
0\end{array}$ & 38 日 & $\begin{array}{l}6.6 \sim 10.4 \\
\text { A7.7 }\end{array}$ & - & 灰白色下痢 & 0(0)( & 5 & 体重增加の障害少し & \# \\
\hline $84 \sim 91$ & $\begin{array}{l}\hat{8} 5 \\
+3\end{array}$ & 27日 & $\begin{array}{l}3.9 \sim 6.8 \\
\text { A } 5.5\end{array}$ & - & 白痢 & (2) - - - (0)-0 & & 再発ありて 5 回投与 & \# \\
\hline
\end{tabular}

注 1. A : 平均体重, $\mathrm{T}:$ 体温, $\bigcirc: 40 \mathrm{mg} / \mathrm{kg}, \odot: 40 \mathrm{mg}+20 \mathrm{mg} / \mathrm{kg}$, ():20mg $+20 \mathrm{mg} / \mathrm{kg}, \oplus: 20 \mathrm{mg}+$ $10 \mathrm{mg} / \mathrm{kg}, \bigcirc: 20 \mathrm{mg} / \mathrm{kg}, \triangle: 10 \mathrm{mg} / \mathrm{kg}, \quad$ : 休薬.

日獣会誌 16 (1963) 
ち, いわゆる Baby Pig Scours に相当するものかも知 れない。この点についてはさらに検討を加える必要性を 痛感している。

治療した総数は91例に達したが，投薬量の正確を期す るためと，1日1回ないし 2 回の投与で, しかも最少量 で有効持続時間を長く保たしめるためすべて筋肉内注射 によった．多頭飼育による集団発生に対しては飼料に混 与するか，または経口的に粉末を投与することが望まれ るが，実際問題として哺乳子豚では母豚に多量投与する ことにより母乳中への移行を期待するの他なく, 罹病中 の哺乳は必らずしも活発ではない，また幼豚以上の豚に おいても食欲の減退もしくは欠損があって確実に服用さ せることが難かしい，

さらに内服による投薬は作業が比較的煩雑であり, こ れに対して $10 \%$ 液の注射は単位体重当りの投与量の調節 が簡単である. 中豚以上の内服牥さらに不便で, 腹腔内 注射法もこれまた保定に難があり実施は容易でない。

本例での細菌培養は一部について好気的偪通寒天に 塗抹したのみであるが，サルファジメトキシンの効果は 全例に認められた. $40 \mathrm{mg}+20 \mathrm{mg} / \mathrm{kg}$ 打よび $40 \mathrm{mg} / \mathrm{kg}$ の 投与例はいずれも治効が顕著であり，前項に述べたよう に治療期間を短縮している.このことは実際問題として 極めて重要なことである.

なお子豚および中豚での類便の虫卵検査はセロファン 厚層法により別に実施した。 子豚では桿虫卵は全例に見 られず，中豚以上のもので肥育したものでは回虫卵ない 乙回虫虫体（主殺時）は1例子検出されなかった。

駆虫は一定の方法で期間を注㜔定めて別に行なってい る. 寄生虫性ないし病原細菌およびウイルス性の伝染性 胃腸炎は全然別個に考えるべきであうう。

副作用人の場合に見られるような自覚症状が認め難 いのであるが，とくに不快感や食欲の不振などの例は全 く見られなかった，皮膚疹や注射部位の硬結腫脹も全例 に認めなかった。

ほとんどすべての例において治療の進むにつれて食欲
が回復した。

\section{IIIむすび}

われわれは人におけると同様ないしはそれに近い方法 で豚に持絸性サルファ剤のひとつであるサルファジメト キシンを筋注して，血中濃度を測定し，さらに91例の子 豚および中豚の下痢症に対して治療を試みた。

1) 初回に $20 \mathrm{mg} / \mathrm{kg}$ の筋注後 8 時間目に再度 $10 \mathrm{mg} /$ $\mathrm{kg}$ の追加注射を試みるか, $40 \mathrm{mg} / \mathrm{kg}$ の 1 日 1 回の投与で $3 \mathrm{mg} / \mathrm{dl}$ 以上の高い血中濃度が 24 時間以上維持され, こ の投与法拉よび投与量は従来用いられてきたサルファ郕 の投与水準に比して著るしく低いものである.

2)血中濃度の測定成績から判明した上記の投与水準は 子豚および中豚に頻発する下㾥症の治療に対して十分有 効であることが分った.

3）とくに記すような副作用は 1 例も認められなかっ た.

終りに臨みご指導とご校閲を賜わりました東大農学部

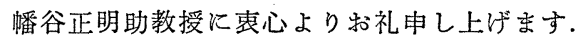

な特本報告に使用したサルフフジメトキシンは中外筡 薬株式会社より試供を受けたものであることを附記いた します。

\section{文献}

1) Detweiler, D.K., Scheidy, S.F.: Advance in Veterinary Science Vol. I, Academic Press, New York p.73 (1953). 2) Dunne, H.W.: Diseases of Swein, Iowa State College Press, Iowa, p. 374(1958). 3) Faustini, R., Vaghi, M.A.: A.J. Vet. Res.,23, 65 (1962). 4) Florestano, H.H., Bahler, M.E. : J.A.V.M.A., 121，474 (1952)。 5) 越智勇一: 家畜 伝染病, 南江堂, 東京 p. 8 (1958). 6) 佐野 肇, 大 家 宏, 武本紀久子, 丸山らじ子, 岩田和夫: The Chemotherapy, 9，4，261 (1961). 7) 杉浦邦紀, 小峰 仙一，藤尾成德：日獣会誌，6，8，274 (1958)。 8)

Welsh, M., Schroeder, C.R., et al : Proc. 50 th Ann. Mtg. U.S. Livestock San Assn p. 213 (1946). "家畜 に対するサルファ剤の応用”シュネラーら著, 東京大学 農学部家畜外科教室訳より引用.

Clinical Application of Sulfadimethoxin to Diarrhea in Swine

S. Motoyoshi, Y. Kano and T. Miura

(Livestock Farm, University of Tokyo)

SUMMARY

Sulfadimethoxin is regarded in human medicine as a long-acting sulfonamide. It is characteristic of this drug that a high and prolonged blood level is maintained after medication of a low dosage of the drug.

Veterinary medicine to administera high dosage of sulfonamide. In this examination, however, some effect was obtained from smaller dosages than those conventionally used for swine.

The first method employed consisted of intramuscular injection of $20 \mathrm{mg}$ per $\mathrm{kg}$ of body weight, which was followed by that of $10 \mathrm{mg} / \mathrm{kg} 8$ hours later. In this case, blood levels of $3.5 \sim 3.9 \mathrm{mg} \%$ were maintained in swine 24 hours after the initial administration.

In another method, swine were given a single dose of $40 \mathrm{mg} / \mathrm{kg}$ and showed blood levels of $2.7 \sim$ $3.5 \mathrm{mg} \% 24$ hours after administration. In these trials, $10 \%$ solution of sulfadimethoxin in sterilized water was used.

These methods gave good results in experimental treatment of bacterial diarrhea of swine in 91 cases.

No marked side-effect was seen in any case. 